\title{
ЕФЕКТИВНІСТЬ КОМПЛЕКСНИХ РЕАБІЛІТАЦІЙНИХ ЗАХОДІВ У ХВОРИХ НА НЕЙРОПАТІЮ ЛИЦЕВОГО НЕРВА В РАННЬОМУ ВІДНОВНОМУ ПЕРІОДІ
}

\author{
๑О. А. Козьолкін, С. О. Мєдвєдкова, М. П. Пухальський, К. А. Рунчева \\ Запорізький державний медичний університет
}

РЕЗЮМЕ. Нейропатія лицевого нерва (НЛН) зустрічається найчастіше серед патологій черепних нервів. НЛН призводить до погіршення якості життя, що проявляється у вигляді тривалої тимчасової непрацездатності. Між тим, питання діагностики, лікування, реабілітації та профілактики уражень НлН на сьогодні залишаються недостатньо вивченими.

Мета - оцінити ефективність комплексних лікувальних заходів та їх вплив на динаміку відновлювальних процесів у хворих на нейропатію лицевого нерва залежно від терміну початку реабілітації.

Матеріал і методи. Нами було проведено комплексне реабілітаційне лікування 74 пацієнтів із НлН. Середній вік хворих склав $(42,6 \pm 5,5)$ років, кількість чоловіків - 44 (59 \%), жінок - 30 (41 \%). Усі пацієнти були поділені на дві групи: в першу увійшли ті, що почали курс реабілітації одразу після гострого періоду (10-14 доба), (n=49, середній вік $(44,5 \pm 6,46)$ років), у другу - ті, яким розпочали реабілітацію пізніше (20-30 доба), (n=25, середній вік (38,8 2,9) років).

Результати. У пацієнтів першої групи спостерігали більш позитивну динаміку регресу симптоматики, ніж у другій групі хворих. Після завершення курсу реабілітації значне покращення симптомів спостерігали у 30 хворих (61,2 \%) першої групи, на відміну від другої групи - 9 хворих (36,0 \%) зі значним покращенням.

Висновки. 1. Реабілітаційне лікування хворих на нейропатію лицевого нерва має бути комплексним, патогенетично обґрунтованим, із застосуванням різних методів і засобів, з активною участю пацієнтів.

2. Лікувально-реабілітаційний комплекс створюється для кожного пацієнта індивідуально, залежно від вираження неврологічних розладів і динаміки відновлювальних процесів.

3. Комплексні лікувально-реабілітаційні заходи ефективніші при проведенні їх у ранній термін, одразу після закінчення гострого періоду захворювання.

КлючОВІ СлОВА: нейропатія лицевого нерва; комплексна реабілітація.

Вступ. Нейропатія лицевого нерва (НЛН) серед патологій черепних нервів трапляється найчастіше, вона складає від 2 до 5 \% захворювань периферійної нервової системи запально-дегенеративного характеру і посідає одне з перших місць за частотою серед мононевритів та мононейропатій [1]. Ця хвороба в середньому вражає 35 осіб на 100000 населення на рік.

Нейропатія лицевого нерва призводить до погіршення якості життя, що проявляється у вигляді тривалої тимчасової непрацездатності. У $18,0-26,0$ \% спостережень залишається косметичний дефект, що обумовлює високу медико-соціальну дезадаптацію та розлади психоемоційної сфери [2].

Пацієнти з НлН часто мають порушення мімічної мускулатури, що проявляється в неспроможності висловлювати емоції $[3,4]$.

Нейропатія лицевого нерва проявляється одностороннім парезом або паралічем мімічної мускулатури обличчя. В генезі НлН різної етіології велике значення надається такій схемі змін «ішемія - набряк - стискання». Довготривала ішемія викликає погіршення мікроциркуляції та судинного тонусу, набряк нерва, компресію у каналі лицевого нерва (ЛН), що призводить до погіршення провідності по ньому, виникнення вторинних судинних розладів [5-7].
Основний клінічний прояв НЛН - це слабкість мімічних м'язів обличчя на ураженій стороні, що призводить до асиметрії обличчя. Крім цього, офтальмологічні симптоми, неможливість закрити око, сльозотеча та слиновиділення, розлади слуху та смаку залежно від рівня ураження лицевого нерва можуть з'явитися на ураженій стороні $[8,9]$.

Принципово важливою залишається проблема обґрунтованого комплексного та диференційного підходу при лікуванні нейропатії лицевого нерва, що $є$ основою успішної терапії і запобігання в першу чергу структурним ушкодженням нервової і м'язової тканин [10].

Мета - оцінити ефективність комплексних лікувальних заходів та їх вплив на динаміку відновлювальних процесів у хворих на нейропатію лицевого нерва залежно від терміну початку реабілітації.

Матеріал і методи дослідження. На базі КНП «Запорізька міська лікарня № 6" у відділенні нейрореабілітації було проведено комплексне лікування 74 хворих на нейропатію лицевого нерва, 3 них 44 особи - чоловіки (59\%), 30 (41\%) осіб - жінки. Вік обстежуваних пацієнтів варіював від 18 до 65 років і в середньому склав $(M \pm \sigma)(42,6 \pm 5,5)$ років. Кількість пацієнтів віком до 30 років склала 21 (28,4 \%), середнього віку (30-60 років) - 40 (54,0\%), похилого віку (старше 60 років) - 13 (17,6 \%). 
Огляди літератури, оригінальні дослідження, погляд на
У всіх пацієнтів спостерігалось одностороннє ураження лицевого нерва, при цьому у 54,1 \% хворих була правостороння, а у 45,9 \% - лівостороння локалізація ураження.

Критеріями включення для проведення дослідження були наявність у пацієнтів нейропатії лицевого нерва, надходження до неврологічного відділення на перший курс реабілітації, вік від 18 до 65 років.

Критеріями виключення - наявність у пацієнтів, котрі проходили повторний курс реабілітації, центрального паралічу лицевого нерва, нейропатії лицевого нерва.

До надходження у відділення нейрореабілітації всі пацієнти отримували курс медикаментозного лікування згідно з загальноприйнятим протоколом.

При госпіталізації хворих у відділення нейрореабілітації ми оцінювали неврологічний статус хворих на нейропатію лицевого нерва, а саме дані про початок захворювання, наявність згладженості лобних і носогубних складок, лагофтальму, опущення кута рота, зміни зубної формули.

Для оцінки ефективності реабілітації досліджували динаміку відновлювальних процесів, насамперед регресу лагофтальму та зубної формули. Пацієнти були поділені на дві групи. Перша група - ті, що почали курс реабілітації одразу після гострого періоду (10-14 доба). Їх частка склала 49 осіб, середній вік становив $(44,5 \pm 6,46)$ років. У другу групу увійшли 25 хворих віком $(38,8 \pm 2,9)$ років, котрі розпочали реабілітацію пізніше, на 2030 добу від початку маніфестації симптомів захворювання.

Усім хворим на нейропатію лицевого нерва призначали комплексне реабілітаційне лікування, яке включало голкорефлексотерапію, лікувальну гімнастику, електростимуляцію апаратом «Міотон-2», лікувальний масаж обличчя та шийно-комірцевої ділянки, медикаментозну терапію (антихолінестеразні, нейромедіатори, судинні препарати, вітаміни групи В і таке інше).

Із фізіотерапевтичних методів використовували електростимуляцію. Вона $\epsilon$ патогенетично обґрунтованим і ефективним методом відновлення рухових функцій на основі стимуляції регенерації та ремієлінізації нервових волокон лицевого нерва, відновлення провідності нервовими волокна- роблему, випадок з практики, короткі повідомлення ми та електрозбудливості нейром'язового апарату, покращення тканинної трофіки та кровообігу. Курс лікування в середньому включав проведення 10-15 процедур.

Ефективність голкорефлексотерапії при нейропатії лицевого нерва обумовлена подразненням неушкоджених аксонів у лицевому нерві, що сприяє зменшенню його набряку і стимулює процеси відновлення функції.

Масаж проводили з використанням різних прийомів, на стороні ураження - тонізуючий, а на здоровій стороні - релаксуючий. Використовували погладжування, розтирання, безперервну вібрацію кінцем середнього пальця, постукування. Тривалість - 5-10-15 хв. Курс лікування - 1215 процедур, щодня або через день.

Лікувальна гімнастика відіграє важливу роль у відновному періоді. Перед кожною вправою обов'язково розслаблюють м'язи, особливо на здоровому боці. На боці ураження вправи здійснювались рукою пасивно, а при появі мінімальних активних рухів - активно за допомогою руки. Кожну вправу повторювали 4-5 разів з паузами для відпочинку, вправи для очей - 2-3 рази. Процедури проводили 2-3 рази на день.

Результати й обговорення. Використання комплексних лікувально-реабілітаційних заходів у раньому відновному періоді показало вагоме покращення клініко-неврологічної картини.

У пацієнтів першої групи спостерігалася позитивніша динаміка регресу симптоматики, насамперед лагофтальму, ніж у другій групі хворих. Була встановлена достовірна відмінність показників залежно від початку реабілітаційних заходів $\left(\chi^{2}=13,021\right.$ р<0,01) (табл. 1).

Зміни зубної формули у хворих першої групи на момент виписування були такими: кількість видимих зубів при оскалюванні становила 3-4 зуби (51,1 \%), 1-2 зуби (28,9 \%), 0-1 зуб (8,9 \%), 0-0,5 зуба $(11,1 \%)$.

У другій групі пацієнтів показники відрізнялись: 3-4 зуби при оскалюванні (22,7 \%), 1-2 зуби (18,2 \%), 0-1 зуб (27,3 \%), 0-0,5 зуба (31,8 \%) $\quad\left(\chi^{2}=10,399\right.$; p<0,015) (рис. 1).

Після завершення курсу реабілітації зі значним покращенням неврологічної картини було виписано більше пацієнтів з першої групи, частка яких складала $61,2 \%$, тоді як у другій групі - всього 36,0 \% (табл. 2).

Таблиця 1. Динаміка відновлення лагофтальму

\begin{tabular}{|l|c|c|c|}
\hline \multicolumn{1}{|c|}{ Групи пацієнтів } & $\begin{array}{c}\text { Лагофтальм збережений, } \\
\text { n(\%) }\end{array}$ & Симптом вій, n (\%) & Регрес лагофтальму, n (\%) \\
\hline Перша група & $6(13,3)$ & $34(75,6)$ & $5(11,1)$ \\
\hline Друга група & $12(50)$ & $8(33,3)$ & $4(16,7)$ \\
\hline
\end{tabular}


Огляди літератури, оригінальні дослідження, погляд на проблему, випадок з практики, короткі повідомлення

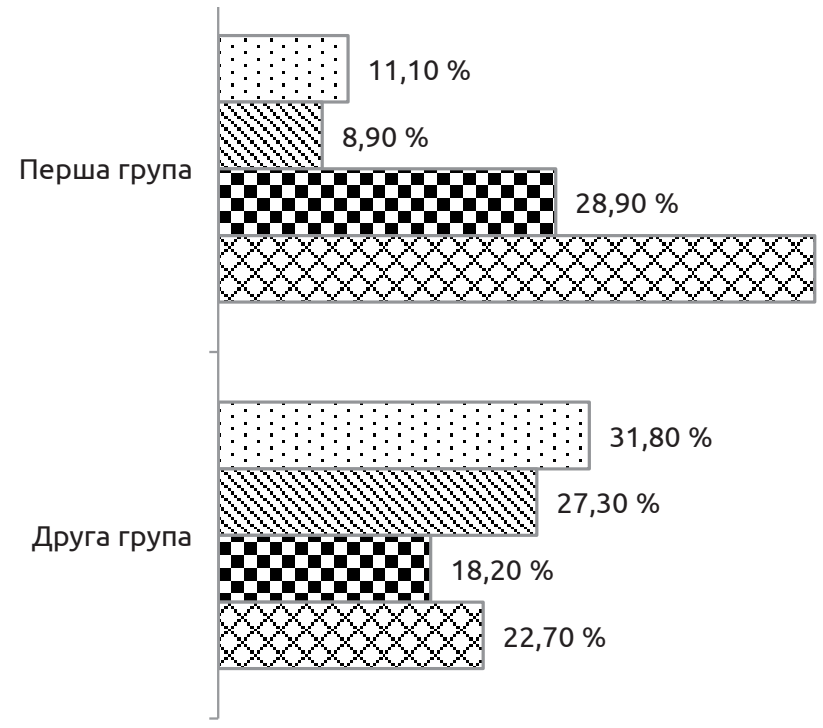

\author{
口При оскалюванні зубів на \\ ураженій стороні видно 0-0,5 зуба \\ $51,10 \%$ बПри оскалюванні зубів на \\ ураженій стороні видно 0,1 зуба \\ 口При оскалюванні зубів на \\ ураженій стороні видно 1,2 зуба \\ ФПри оскалюванні зубів на \\ ураженій стороні видно 3-4 зуби
}

Рис. 1. Динаміка змін зубної формули.

Таблиця 2. Ефективність лікування хворих на нейропатію лицевого нерва

\begin{tabular}{|l|c|c|}
\hline \multirow{2}{*}{ Стан при виписуванні } & \multicolumn{2}{|c|}{ Групи пацієнтів, \% } \\
\cline { 2 - 3 } & перша & друга \\
\hline Значні покращення & 61,2 & 36 \\
\hline Незначні покращення & 38,8 & 64 \\
\hline
\end{tabular}

Проведене нами дослідження показало, що застосування комплексних реабілітаційних заходів у хворих на нейропатію лицевого нерва сприяє відновлювальним процесам і позитивно впливає на перебіг захворювання.

Висновки. 1. Реабілітаційне лікування хворих на нейропатію лицевого нерва має бути комплексним, патогенетично обґрунтованим, із застосуванням різних методів і засобів, з активною участю пацієнтів.

2. Лікувально-реабілітаційний комплекс створюється для кожного пацієнта індивідуально, за- лежно від вираження неврологічних розладів і динаміки відновлювальних процесів.

3. Комплексні лікувально-реабілітаційні заходи більш ефективні при проведенні їх у ранній термін, одразу після закінчення гострого періоду захворювання.

Перспективи подальших досліджень. Планується розроблення більш ефективних лікувально-реабілітаційних комплексів для хворих на нейропатію лицевого нерва з застосуванням їх у ранньому періоді для покращення відновлювальних процесів.

\title{
ЛІТЕРАТУРА
}

1. Альперович П. М. Лечение и профилактика невритов лицевого нерва и их последствий : метод. рекомендации / П. М. Альперович, В. Д. Билык, А. Г. Корнийчук. - Винница : Винницк. мед. ин-т., 1981. - С. 16.

2. Нове у лікуванні невропатії лицевого нерва / $€$ Л. Л. Мачерет, Т. В. Кулемзіна, Г. М. Чуприна [та ін.]. - Донецьк : Каштан, 2004. - С. 201.

3. Macgregor F. C. Facial disfigurement: problems and management of social interaction and implications for mental health / F. C. Macgregor // Aesthetic Plastic Surgery. 1990. - No. 14 (1). - P. 249-257.

4. Valente S. M. Visual disfigurement and depression. Plastic Surgical Nursing / S. M. Valente // Official Jour-

nal of the American Society of Plastic and Reconstructive Surgical Nurses. - 2004. - No. 24 - P. 140-146.

5. Неврологія: підручник / І. А. Григорова, Л. І. Соколова, Р. Д. Герасимчук [та ін.] / за ред. І. А. Григорової, Л. І. Соколової. - 3-є вид. переробл. та допов. - К. : Медицина, 2020. - С. 259-263.

6. Пітик М. І. Невропатія лицевого нерва у дітей: деякі аспекти діагностики та лікування / М. І. Пітик, І. І. Ліскевич // Журнал неврології ім. Б. М. Маньковського. 2015. - T. 3, № 1. - С. 80-85.

7. Рибалов О. В. Сучасний погляд на виникнення та розвиток периферичних уражень лицьового нерва / О. В. Рибалов // Актуальні проблеми сучасної медици- 
Огляди літератури, оригінальні дослідження, погляд на проблему, випадок з практики, короткі повідомлення ни : Вісник Української медичної стоматологічної академії. - 2014. - № 4 (48). - С. 286-290.

Laryngol-112. - 197-201

9. Jackson C. G. The facial nerve. Current trends

8. Axelsson S. Outcome of treatment with valacyclovir and prednisone in patients with Bell's palsy / S. Axelsson, S. Lindberg, A. Stjernquist-Desatnik // Ann. Otol. Rhinol indiagnosis, treatment, and rehabilitation / C. G. Jackson, P. G. Von Doersten // Medical Clinics of North America. 2011. - № 83. - P. 179-195.

\title{
REFERENCES
}

1. Alperovich, P.M., Bilyk, V.D., Korniychuk, A.G. (1981). Liechenie I profilaktika nievritov litsevogo nierva i ikh posliedstviy: Metod. rekomendatsii [Treatment and prevention of facial nerve neuritis and their consequences: Method. Recommendations]. Vinnitsa: Vinnitskiy med. univ. [in Russian].

2. Macheret, E.L., Kulemzina, T.W., \& Chupryna, G.M. (2004). Nove u likuvanni nevropatii lytsevoho nerva [New in the treatment of facial nerve neuropathy]. Donetsk: Kashtan [in Ukrainian].

3. Macgregor, F.C. (1990). Facial disfigurement: problems and management of social interaction and implications for mental health. Aesthetic Plastic Surgery, 14 (1), 249-257.

4. Valente, S.M. (2004). Visual disfigurement and depression. Plastic Surgical Nursing. Official Journal of the American Society of Plastic and Reconstructive Surgical Nurses, 24, 140-146.

5. Grigorova, I.A., Sokolova, L.I., \& Gerasymchuk, R.D. (2020). Nevrolohia: pidruchnyk [Neurology. Handbook]. Kyiv: Medicine [in Ukrainian].

6. Pityk, M.I. \& Liskevych, I.I. (2015). Nevrolohia lytsevoho nerva u ditey: deiaki aspecty diahnostyky ta likuvannia [Facial nerve neuropathy in children: some aspects of diagnosis and treatment. Zhurnal nevrolohii im. B.M. Mankovskoho - B. M. Mankovsky Journal of Neurology, 3 (1), 80-85 [in Ukrainian].

7. Rybalov, O.V. (2014). Suchasnyi pohliad na vynyknennia ta rozvytok peryferychnykh urazhen lytsiovoho nerva [A modern view of the onset and development of peripheral lesions of the facial nerve]. Aktualni problemy suchasnoi medytsyny: Visnyk Ukrayinskoi medychnoi stomatolohichnoi akademii - Actual Problems of Modern Medicine: Bulletin of the Ukrainian Medical Dentistry Academy, 4 (48), 286-290 [in Ukrainian].

8. Axelsson, S., Lindberg, S., \& Stjernquist-Desatnik, A. (2003). Outcome of treatment with valacyclovir and prednisone in patients with Bell's palsy. Ann. Otol. Rhinol. Laryngol., 112, 197-201.

9. Jackson, C.G., \& Von Doersten, P.G. (2011). The facial nerve. Current trends indiagnosis, treatment, and rehabilitation. Medical Clinics of North America, 83, 179-195.

\section{ЭФФЕКТИВНОСТЬ КОМПЛЕКСНЫХ РЕАБИЛИТАЦИОННЫХ МЕРОПРИЯТИЙ У БОЛЬНЫХ НЕЙРОПАТИЕЙ ЛИЦЕВОГО НЕРВА В РАННЕМ ВОССТАНОВИТЕЛЬНОМ ПЕРИОДЕ}

\author{
๑А. А. Козелкин, С. А. Медведкова, Н. П. Пухальский, Е. А. Рунчева \\ Запорожский государственный медицинский университет
}

РЕзЮМЕ. Нейропатия лицевого нерва (НЛН) встречается чаще всего среди патологий черепных нервов. НЛН приводит к ухудшению качества жизни, к длительной временной нетрудоспособности. Сегодня вопросы диагностики, лечения, реабилитации и профилактики поражений НЛН остаются недостаточно изученными.

Цель - оценить еффективность комплексных лечебных мероприятий и их влияние на динамику восстановительных процессов у больных нейропатией лицевого нерва в зависимости от срока начала реабилитации.

Материал и методы. Нами было проведено комплексное реабилитационное лечение 74 пациентов с НлН. Средний возраст больных - $(42,6 \pm 5,5)$ лет, количество мужчин - 44 (59,5 \%), женщин - 30 (40,5 \%). Все пациенты были поделены на две группы: в первую вошли те, кто начал курс реабилитации сразу после острого периода (10-14 сутки), ( $n=49$, средний возраст $(44,5 \pm 6,46)$ лет), во вторую - начавшие реабилитацию позже (20-30 сутки), ( $n=25$, средний возраст 38,8 2,9 лет).

Результаты. У пациентов первой группы наблюдалась более положительная динамика регресса симптоматики, чем во второй группе больных. После завершения курса реабилитации значительное улучшение симпто-

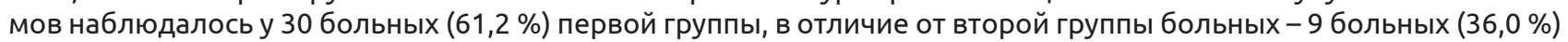
со значительным улучшением.

Выводы. 1. Реабилитационное лечение больных нейропатией лицевого нерва должно быть комплексным, патогенетически обоснованным, с применением различных методов и средств, с активным участием пациентов.

2. Лечебно-реабилитационный комплекс создается для каждого пациента индивидуально, в зависимости от выраженности неврологических расстройств и динамики восстановительных процессов.

3. Комплексные лечебно-реабилитационные мероприятия более эффективны при проведении их в ранние сроки, сразу после окончания острого периода заболевания.

КЛЮчЕВЫЕ СЛОВА: нейропатия лицевого нерва; комплексная реабилитация. 
Огляди літератури, оригінальні дослідження, погляд на проблему, випадок з практики, короткі повідомлення

EFFECTIVENESS OF COMPLEX REHABILITATION MEASURES IN PATIENTS WITH FACIAL NERVE NEUROPATHY IN THE EARLY RECOVERY PERIOD

\section{@O. A. Kozyolkin, S. O. Medvedkova, M. P. Pukhalskyi, K. A. Runcheva Zaporizhzhia State Medical University}

SUMMARY. Facial nerve neuropathy (FNN) is one of the most common pathology of the cranial nerves. Facial nerve neuropathy leads to a deterioration in quality of life, which manifests itself in the form of prolonged temporary disability. Meanwhile, the issues of diagnosis, treatment, rehabilitation and prevention of facial nerve neuropathy lesions remain insufficiently studied today.

The aim - to evaluate the effectiveness of complex therapeutic measures on the dynamics of recovery processes in patients with facial nerve neuropathy depending on the date of onset of rehabilitation.

Material and Methods. We carried out complex rehabilitation treatment for 74 patients with FNN. The average age of patients is $42.6 \pm 5.5$, the number of men -44 (59.5\%), women -30 (40.5\%). Patients were divided into two groups: the first - those who began rehabilitation immediately after the acute period (10-14 days), ( $n=49$, average age 44.5 \pm 6.46 ). The second group included 25 patients (average age 38.8 2 2.9), who began rehabilitation later (20-30 days).

Results. Patients in the first group had a more positive dynamics of regression of symptoms than in the second group of patients. After completion of the rehabilitation course, a significant improvement in symptoms was observed in 30 patients $(61.2 \%)$ of the first group, in contrast to the second group of patients -9 patients ( $36.0 \%)$ with a significant improvement.

Conclusions: 1) Rehabilitation treatment of patients with facial nerve neuropathy should be comprehensive, pathogenetically sound with the use of various methods and tools, with the active participation of patients.

2) Therapeutic - rehabilitation complex created for each patient individually depending on the severity of neurological disorders and the dynamics of recovery processes.

3) Comprehensive treatment and rehabilitation measures are more effective when they were carried out at an early stage, immediately after the end of the acute period of the disease.

KEY WORDS: facial nerve neuropathy; comprehensive rehabilitation.

Отримано 12.05.2021 